\title{
ASOSIATIF LAYANAN TENAGA PERPUSTAKAAN SEKOLAH DENGAN MOTIVASI MEMBACA SISWA DI KABUPATEN BOGOR
}

\section{ASSOCIATIVE OF SCHOOL LIBRARY SERVICES WITH MOTIVATION READING STUDENTS IN BOGOR DISTRICT}

\author{
Wahyu Bagja Sulfemi ${ }^{1}$ Teti Luthfianti ${ }^{2}$ \\ STKIP Muhammadiyah Bogor \\ surel: wahyubagja@gmail.com
}

\begin{abstract}
Abstrak : Penelitian ini mengenai asosiatif persepsi siswa tentang layanan perpustakaan sekolah dengan motivasi membaca siswa di Madrasah Aliyah Negeri (MAN) 2 BOGOR. Penelitian ini dilaksanakan di Madrasah Aliyah Negeri 2 Kabupaten Bogor dengan jumlah popilasi 1168 dengan sistem pengambilan sampel menggunakan teknik random sampling sebanyak 117 siswa. Hasil penelitian ini membuktikan bahwa Persepsi Siswa Tentang Layanan Perpustakaan Sekolah di MAN 2 Bogor berkriteria sedang yaitu sebesar 50.43\%, Motivasi Membaca di MAN 2 Bogor berkriteria tinggi sebesar 55,56\%. Hasil pengujian terhadap koefisien yang diperoleh dari hasil perhitungan bahwa $r_{x y}$ 0,579 signifikan, sehingga terdapat hubungan antara Persepsi Siswa Tentang Layanan Perpustakaan Sekolah dengan Motivasi Membaca di MAN 2 Bogor berdasarkan hasil perhitungan $t_{\text {hitung }}$ sebesar 7,615 dan $t_{\text {tabel }}$ dengan derajat kebebasan $(\mathrm{dk})=\mathrm{N}-2$ dan $\alpha=0,05$ sebesar 2,000. Hal ini berarti $t_{\text {hitung }}>$ dari $t_{\text {tabel }}$ yakni 7,615 >2,000.
\end{abstract}

Kata Kunci : Layanan perpustakaan, Motivasi, dan membaca

Abstract : This study is about the associative perceptions of students about school library services with motivation to read students in State Madrasah Aliyah (MAN) 2 Bogor. This research was carried out in the State 2 Madrasah Aliyah Bogor Regency with a number of poplets of 1168 with the sampling system using a random sampling technique of 117 students. The results of this study prove that Student Perceptions of School Library Services in Bogor State 2 Madrasah Ali 2 are moderate, which is equal to $50.43 \%$, Reading Motivation in Madrasah Aliyah Negeri 2 Bogor has a high criteria of 55.56\%. The test results on the coefficients obtained from the calculation result that $r_{-}$(xy) 0.579 is significant, so there is a relationship between Student Perception of School Library Services and Reading Motivation in Bogor State 2 Madrasah Aliyah based on the calculation of $\mathrm{t}$-count of 7.615 and $\mathrm{t}$-tabel with degrees of freedom $(\mathrm{dk})=\mathrm{N}-2$ and $\alpha=0.05$ of 2,000 . This means that $\mathrm{t}$ count> from $t$ table is $7.615>2,000$.

Keywords: Library services, motivation, and reading

\section{PENDAHULUAN}

Membaca merupakan salah satu tuntutan dalam kehidupan masyarakat modern. Membaca adalah sebuah aktivitas yang tidak asing bagi masyarakat, bahkan kegiatan membaca sudah diperkenalkan sejak usia dini. Dengan membaca, kemampuan berpikir manusia akan semakin terasa dan berkembang. Ilmu pengetahuanpun akan bertambah dan meningkatkan kualitas Sumber Daya Manusia terutama di eraglobalisasi ini. Dengan membaca kita dapat mengetahui berbagai pengetahuan, tanpa harus melihatnya secara langsung. 
Banyak orang membaca kata demi kata, bahkan mengucapkannya secara cermat, dengan maksud dapat memahami isi bacaannya. Maka dari itu, membaca menjadi sebuah kebutuhan manusia agar dapat menghadapi persaingan dengan bangsa-bangsa lain di dunia. Tidak jarang realita harus kontra dengan harapan yang telah dirumuskan. Kegiatan membaca yang terlihat mudah, ternyata tidak semua orang merasa nyaman dengan kegiatan tersebut khususnya pada kalangan generasi muda.

Hasil penelitian United Nations Educational Scientific and Cultural Organization (UNESCO) menyebutkan rata-rata dalam satu tahun masyarakat Amerika Serikat membaca buku antara 20 sampai 30 judul buku. Masyarakat di Jepang membaca 10 sampai 15 judul buku, dan di Negara Asean selain Indonesia masyarakatnya membaca 2-3 judul buku. (http://m.portalmadura.com/budaya-baca-masyarakat-indonesia-masih-nolpersen-2267)

Sedangkan di Indonesia, menurut data UNESCO, masyarakatnya membaca 0 sampai 1 buku pertahunnya. Rendahnya minat baca masyarakat indonesia dengan asumsi dalam setiap 1000 orang hanya satu orang yang membaca, kondisi ini tentu sangat memprihatinkan. Bahkan, Taufiq Ismail pernah membandingkan budaya baca dikalangan pelajar saat ini. Ia menyebutkan rata-rata lulusan SMA di Jerman membaca 32 judul buku, di Belanda 30 buku, Rusia 12 buku, Singapura 6 buku, Malaysia 6 buku, Brunei 7 buku, sedangkan indonesia nol buku. Taufiq Ismail menyebut kondisi ini dengan istilah "tragedi nol buku", yaitu generasi yang tidak membaca satu pun buku dalam satu tahun, generasi yang rabun membaca. (http://www.paud-dikmas.kemdikbud.go.id/berita/8450.html)

Banyak faktor yang mempengaruhinya salah satunya karena perkembangan zaman yang begitu canggih, yaitu dengan adanya layanan internet yang seharusnya digunakan untuk membaca informasi-informasi positif, justru digunakan untuk kegiatan yang sama sekali tidak ada hubungannya dengan membaca, seperti game online, melihat video, bahkan untuk mengakses hal-hal negatif.

Kurangnya minat baca pada kalangnan remaja karena tidak adanya motivasi untuk membaca buku. Motivasi merupakan suatu proses psikologis sehingga menggerakkan perilaku atau dorongan untuk mencapai suatu tujuan yang diharapkan. Artinya bahwa motivasi merupakan sejumlah kondisi yang mendorong, menggerakkan serta menghidupkan perilaku, kemudian mengarahkan perilaku tersebut kepada tujuan dan mempertahankannya hingga tercapainya target yang diinginkan. Dengan tercapainya tujuan tersebut maka terpenuhilah kepuasan dalam dirinya.

Perpustakaan sebagai lembaga nonprofit merupakan salah satu unit yang menyediakan jasa layanan informasi. Jadi dalam kegiatan layanan jasa informasi perpustakaan tidak hanya berfokus pada layanan informasi saja tetapi juga harus memperhatikan reaksi dari pengguna yang memanfaatkan jasa layanan. Perpustakaan perlu menerapkan manajemen yang strategis dan kebijakan yang terus diefektifkan. Perpustakaan yang unggul adalah perpustakaan yang dapat mengetahui kebutuhan dan memuaskan pelanggannya.

Secara umum dapat dikatakan bahwa pada dasarnya keinginan pengguna yang berhubungan dengan perpustakaan adalah mengharapkan sesuatu yang lebih baik dan dapat memuaskan. Sesuatu yang didapat dalam pelayanan jasa tidak lain adalah kepuasan yang diterima dari pemberi jasa dalam hal ini perpustakaan. Untuk itu, perpustakaan selalu dituntut untuk meningkatkan kualitas pelayanan krpada pengguna dan selalu mengembangkan nilai tambah yang lebih baik, dengan cara seperti itu perpustakaan dapat menarik minat pengunjung dan mempertahankan pengguna yang telah ada. Jika pengguna merasa tidak puas mereka akan kecewa dan perpustakaan mempunyai citra yang jelek dimata pengunjung dan bahkan mempengaruhi pengunjung yang lain, sehingga perpustakaan akan ditinggalkan oleh penggunanya.

Dalam mendapatkan layanan perpustakaan sekolah pengguna selalu ingin mendapatkan yang terbaik. Pengguna akan merasa puas apabila dapat menemukan informasi yang relevan 
dengan kebutuhannya. Pengguna juga akan merasa puas apabila dalam melayani pustakawan bersikap ramah, sopan, penuh kemitraan dan fasilitas-fasilitas yang tersedia juga harus mendukung, sehingga dalam pemanfaatan perpustakaan pengguna akan merasa nyaman dengan fasilitas yang tersedia.

Perpustakaan harus menerapkan strategi dan kebijakan, sehingga dapat mencapai sasarannya. Perpustakaan harus memahami keinginan dan kebutuhan pengguna, agar pengguna loyal terhadap suatu perpustakaan. Hal ini dikarenakan loyalitas pengguna merupakan tujuan akhir dari penyedia jasa seperti perpustakaan sekolah. Melalui riset motivasi membaca ini terhadap layanan perpustakaan dapat diungkap reaksi pengguna terhadap layana perpustakaan sekolah yang mempengaruhi motivasi membaca. Pengguna dapat menilai pelayanan perpustakaan melalui sikap yang mereka tunjukan sewaktu berkunjung ke perpustakaan.

Berdasarkan uraian di atas, maka penyusun merasa terdorong untuk mengkaji dan meneliti lebih lanjut mengenai layanan perpustakaan sekolah dalam melaksanakan tugastugasnya yang berkaitan dengan motivasi membaca siswa. Maka dari itu peneliti mengambil judul "Hubungan Persepsi Siswa tentang Layanan Perpustakaan Sekolah dengan Motivasi Membaca Siswa di MAN 2 Bogor Kecamatan Leuwisadeng”.

Tujuan yang ingin dicapai dalam penelitian ini yaitu : (1) Untuk mengetahui persepsi siswa tentang layanan perpustakaan sekolah MAN 2 Bogor. (2) Untuk mengetahui motivasi membaca siswa MAN 2 Bogor. (3) Untuk mengetahui hubungan persepsi siswa tentang layanan perpustakaan sekolah dengan motivasi membaca siswa MAN 2 Bogor

\section{METOLOGI PENELITIAN}

Penelitian ini menggunakan pendekatan kuantitatif dengan menggunakan jenis penelitian deskriptif dan asosiatif. Menurut Sugiyono (2010: 56) penelitian deskriptif adalah penelitian yang dilakukan untuk mengetahui nilai variabel mandiri, baik satu atau lebih variabel independen tanpa membuat perbandingan, atau menghubungkan dengan variabel yang lain. Penelitian deskriptif disini bertujuan untuk memperoleh deskripsi atau gambaran mengenai Layanan Perpustakaan dan Motivasi Membaca di MAN 2 Bogor.

Jenis penelitian asosiatif merupakan penelitian yang bersifat menanyakan hubungan antara dua variabel atau lebih. Ada tiga bentuk hubungan dalam penelitian asosiatif, yaitu hubungan simetris, hubungan kausal, dan hubungan interaktif/resiprokal/timbal balik, (Sugiyono, 2010: 57).

Metode pengumpulan data yang digunakan dalam penelitian ini adalah metode survei, yaitu melalui pengumpulan data di lapangan. Sugiyono (2005: 7) mengemukakan bahwa metode survei adalah metode penelitian yang dilakukan pada populasi besar maupun kecil, tetapi data yang dipelajari adalah data dari sampel yang diambil dari populasi tersebut secara acak, sehingga ditemukan kejadian-kejadian relatif, distribusi, dan hubungan-hubungan antar variabel sosiologis maupun psikologis.

Penelitian yang menggunakan metode survei ini, informasi dari sampel dikumpulkan langsung di tempat kejadian secara empirik dengan tujuan untuk mengetahui pendapat dari sampel terhadap objek yang sedang diteliti. Mengingat keterbatasan waktu dalam penelitian ini, maka digunakan cross sectional method yaitu metode penelitian dengan cara mempelajari objek dalam kurun waktu tertentu (tidak berkesinambungan dalam jangka waktu panjang), (Umar, 2002: 45).

Sehingga yang menjadi populasi pada penelitian ini adalah siswa MAN 2 Bogor Tahun Pelajaran 2016/2017 yang berjumlah 1168 siswa. Berdasarkan pendapat Arikunto diatas maka, Sampel yang digunakan dalam penelitian ini sebanyak $10 \%$ siswa dari jumlah populasi yang diambil dari siswa MAN 2 Bogor, hal ini dikarenakan jumlah populasi yang akan diteliti 
mencapai lebih dari 100 orang. Dan sistem pengambilan sampel tersebut secara acak atau menggunakan teknik random sampling sebanyak 117 siswa.

\section{HASIL DAN PEMBAHASAN}

Penelitian ini bertujuan untuk mengetahui apakah ada hubungan Persepsi Siswa Tentang Layanan Perpustakaan Sekolah Terhadap Motivasi Membaca Siswa di MAN 2 Bogor. Pengumpulan data yang dilakukan dalam penelitian ini dengan cara menyebarkan sejumlah daftar pertanyaan (kuesioner atau angket) kepada sampel yang telah ditentukan sebanyak 117 siswa di MAN 2 Bogor. Di dalam daftar pernyataan ini memuat pernyataan yang mengacu pada kedua variabel, yaitu variabel Persepsi Siswa Tentang Layanan Perpustakaan Sekolah (X) dan variabel Motivasi Membaca (Y).

Untuk variabel Motivasi Membaca (Y) dalam penelitian ini, peneliti membagikan kuesioner atau angket kepada 117 siswa di MAN 2 Bogor

Setelah dilakukan perhitungan diperoleh skor terendah 28 dengan skor tertinggi 79 , range skor sebesar 51, Banyak kelas sebanyak 8, Interval kelas sebesar 7, modus sebesar 55,40 median sebesar 55,83, mean sebesar 56, rentang data 51. banyaknya kelas 83 dibulatkan menjadi 8, dan panjang interval 6,37 dibulatkan menjadi 7

Dari data diatas diperoleh Kelas 25-31 diperoleh frekuensi $=1$, nilai tengah $(\mathrm{Y})=28$, nilai $Y^{2}=784$, hasil kali $F . Y=28$ dan hasil dari F. $Y^{2}=784$. Kelas 32-38 diperoleh frekuensi $=$ 2 , nilai tengah $(Y)=35$, nilai $Y^{2}=1225$, hasil kali $F . Y=70$ dan hasil dari F. $Y^{2}=2450$. Kelas 39-45 diperoleh frekuensi $=7$, nilai tengah $(Y)=43$, nilai $Y^{2}=1849$, hasil kali $F . Y=301$ dan hasil dari F. $Y^{2}=12943$. Kelas 46-52 diperoleh frekuensi $=29$, nilai tengah $(\mathrm{Y})=49$, nilai $\mathrm{Y}^{2}=$ 2401, hasil kali F.Y $=1421$ dan hasil dari F. $Y^{2}=69629$. Kelas 53-59 diperoleh frekuensi $=41$, nilai tengah $(\mathrm{Y})=56$, nilai $\mathrm{Y}^{2}=3136$, hasil kali $\mathrm{F}$. $\mathrm{Y}=2296$ dan hasil dari F. $\mathrm{Y}^{2}=128576$. Kelas 60-66 diperoleh frekuensi $=24$, nilai tengah $(\mathrm{Y})=63$, nilai $\mathrm{Y}^{2}=3969$, hasil kali F. $\mathrm{Y}=$ 1512 dan hasil dari F. $Y^{2}=95256$. Kelas 67-73 diperoleh frekuensi $=11$, nilai tengah $(Y)=70$, nilai $Y^{2}=4900$, hasil kali $F . Y=770$ dan hasil dari $F . Y^{2}=53900$. Kelas 74-80 diperoleh frekuensi $=2$, nilai tengah $(Y)=77$, nilai $Y^{2}=5929$, hasil kali $F . Y=154$ dan hasil dari $F . Y^{2}=$ 11858. Sehingga diperoleh jumlah keseluruhan Frekuensi $=117$, Nilai tengah $(Y)=421$, nilai $\mathrm{Y}^{2}=24193$, hasil kali F.Y $=6552$ dan hasil dari F. $\mathrm{Y}^{2}=375396$.

Dari hasil ukuran pemusatan data tersebut untuk lebih jelasnya dapat disajikan dalam bentuk tabulasi data sebagai berikkut .

Tabel Distribusi Frekuseni skor Data (Y) Motivasi Membaca.

\begin{tabular}{|c|c|c|c|}
\hline No & Kelas Interval & Frekuensi Absolut & Frekuensi Relatif \% \\
\hline 1 & $25-31$ & 1 & 0,9 \\
\hline 2 & $32-38$ & 2 & 1,7 \\
\hline 3 & $39-45$ & 7 & 6,0 \\
\hline 4 & $46-52$ & 29 & 24,8 \\
\hline 5 & $53-59$ & 41 & 35,0 \\
\hline 6 & $60-66$ & 24 & 20,5 \\
\hline 7 & $67-73$ & 11 & 9,4 \\
\hline 8 & $74-80$ & 2 & 1,7 \\
\hline & Jumlah & $\mathbf{1 1 7}$ & $\mathbf{1 0 0}$ \\
\hline
\end{tabular}

Untuk lebih memperjelas data yang terdapat pada tabel, di bawah ini disajikan diagram batang mengenai Motivasi Membaca yaitu:

Gambar Diagram Batang Motivasi Membaca 


\section{Gambar Diagram Batang Motivasi Membaca.}

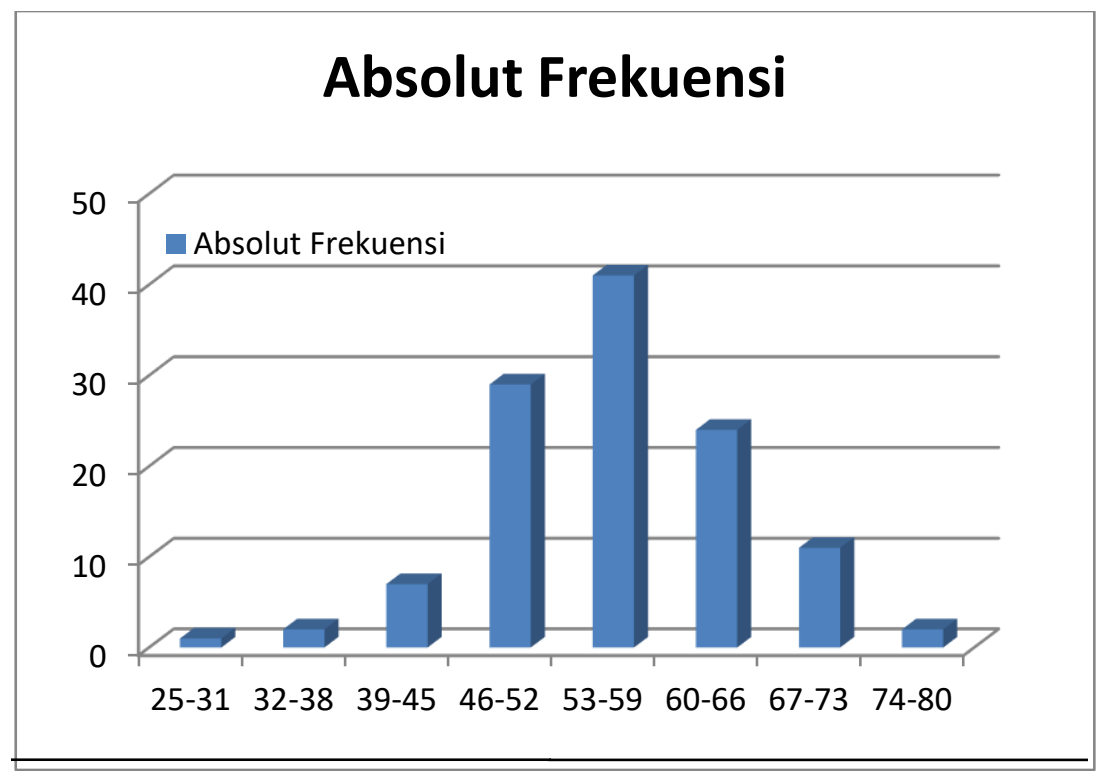

Berdasarkan gambar di atas, dapat dilihat bahwa Motivasi Membaca memiliki nilai diantara 53-59. Untuk mengetahui kecenderungan Motivasi Membaca dapat diketahui dengan perhitungan presentase frekuensi dengan rumus perhitungan presentase yaitu : $\mathrm{P}=\mathrm{f} \quad \mathrm{X}$ $100 \%$ didapat $11,11 \%$ (sangat tinggi)

Berdasarkan rentang 0-80. Hasil perhitungan di atas menunjukkan bahwa Motivasi Membaca berkriteria sangat rendah sebesar 2,56\%, berkriteria sedang sebesar 30,77\%, berkriteria tinggi sebesar 55,56\% dan yang berkriteria Sangat tinggi sebesar 11,11\%. Dengan demikian dapat disimpulkan bahwa Motivasi Membaca di MAN 2 Bogor tergolong dalam kriteria tinggi.

\section{Deskripsi Data Persepsi Siswa Tentang Layanan Perpustakaan Sekolah (X)}

Untuk variabel Persepsi Siswa Tentang Layanan Perpustakaan Sekolah (X) dalam penelitian ini, peneliti membagikan kuesioner atau angket kepada 117 siswa di MAN 2 Bogor - Setelah dilakukan perhitungan diperoleh skor terendah 37 dengan skor tertinggi 79, range skor sebesar 42, Banyak kelas sebanyak 8, kelas interval sebanya 6, modus sebesar 56,79, median sebesar 56,96 dan mean sebesar 56,83, Rumus Rentang Data 42, Banyaknya Kelas7,83 dibulatkan menjadi 8, dan Panjang Interval 5,25 dibulatkan menjadi 6. Dari hasil ukuran pemusatan data tersebut untuk lebih jelasnya dapat disajikan dalam bentuk tabulasi data pada tabel berikut

Tabel Distribusi Frekuseni skor Data (X) Persepsi Siswa Tentang Layanan Perpustakaan Sekolah

\begin{tabular}{|c|c|c|c|}
\hline No & Kelas Interval & Frekuensi Absolut & Frekuensi Relatif \% \\
\hline 1 & $35-40$ & 7 & 6 , \\
\hline 2 & $41-46$ & 2 & 1,7 \\
\hline 3 & $47-52$ & 22 & 18,8 \\
\hline 4 & $53-58$ & 37 & 31,6 \\
\hline 5 & $59-64$ & 31 & 26,5 \\
\hline 6 & $65-70$ & 14 & 12 , \\
\hline 7 & $71-76$ & 2 & 1,7 \\
\hline 8 & $77-82$ & 2 & 1,7 \\
\hline \multicolumn{2}{|r|}{ Jumlah } & 117 & 100 \\
\hline
\end{tabular}


Untuk lebih memperjelas data yang terdapat pada tabel, di bawah ini disajikan diagram batang mengenai Persepsi Siswa Tentang Layanan Perpustakaan Sekolah yaitu:

\section{Gambar Diagram Batang Persepsi Siswa Tentang Layanan Perpustakaan Sekolah}

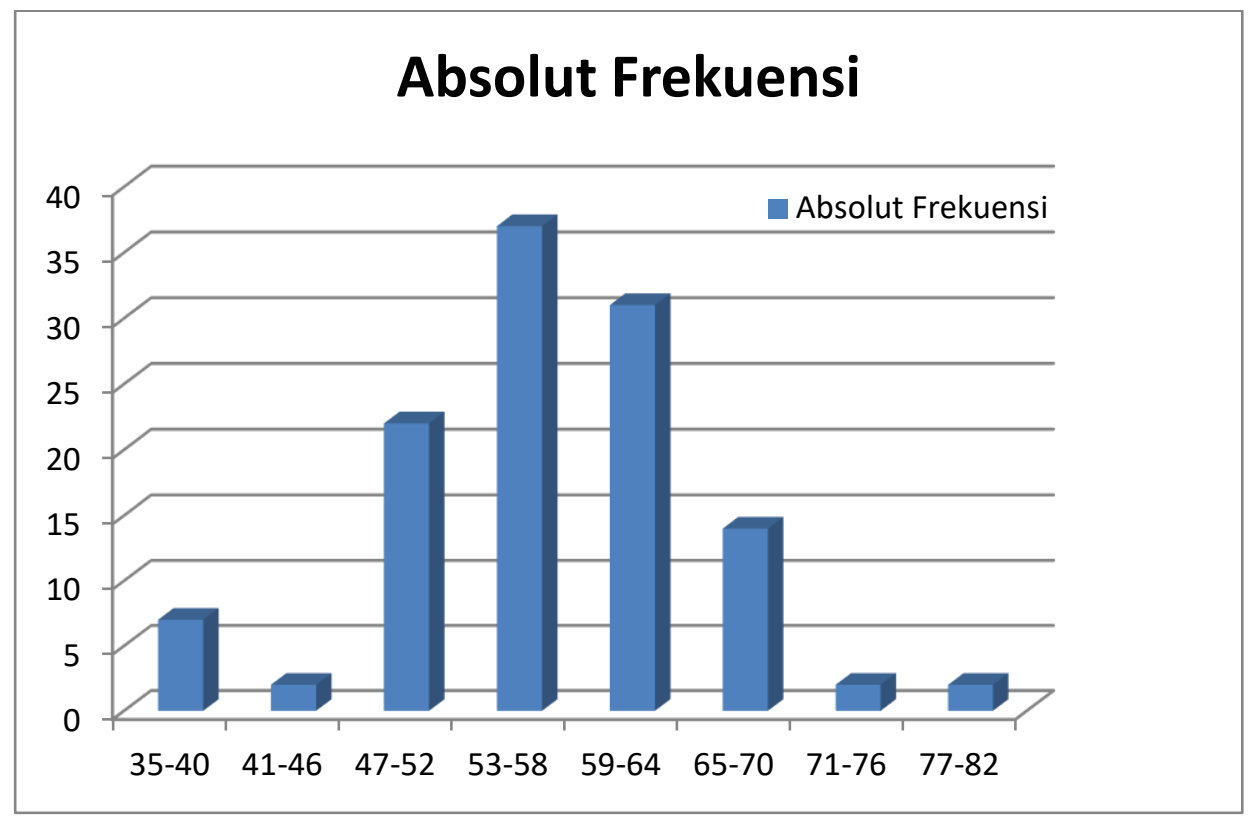

Berdasarkan gambar di atas, dapat dilihat bahwa Persepsi Siswa Tentang Layanan Perpustakaan Sekolah memiliki nilai diantara 53-58. Untuk mengetahui kecenderungan Persepsi Siswa Tentang Layanan Perpustakaan Sekolah dapat diketahui dengan perhitungan peresentase frekuensi dengan rumus perhitungan presentase yaitu: $\mathrm{P}=\mathrm{f} \quad \mathrm{x} 100=3,42 \%$ (Rendah)

Berdasarkan rentang 0-80. Hasil perhitungan di atas menunjukkan bahwa Persepsi Siswa Tentang Layanan Perpustakaan Sekolah berkriteria rendah sebesar 7,69\%, berkriteria sedang sebesar $50.43 \%$, dan yang berkriteria 38,46\% tinggi dan berkriteria Sangat Tinggi sebesar 2,41\%. Dengan demikian dapat disimpulkan bahwa Persepsi Siswa Tentang Layanan Perpustakaan Sekolah di MAN 2 Bogor tergolong dalam kriteria sedang.

Pengujian Korelasional. Analisis koefisien korelasi dimaksudkan untuk mengukur keeratan hubungan (korelasi) antara Variabel Persepsi Siswa Tentang Layanan Perpustakaan Sekolah Dengan Variabel Motivasi Membaca. Penghitungan koefisien korelasi menggunakan rumus product moment dan didasarkan pada hasil penyebaran kuesioner (lampiran)

Analisis koefisien korelasi product moment digunakan untuk menentukan bentuk dan jenis Hubungan Persepsi Siswa Tentang Layanan Perpustakaan Sekolah Terhadap Motivasi Membaca siswa, dimana rumus yang digunakan adalah sebagai berikut $\mathrm{n}=117, \sum \mathrm{X}=$ $6657, \sum Y=6517, \sum X^{2}=371589, \sum Y^{2}=371589, \sum X Y=375751$. Dari data ini dapat ditentukan $\mathrm{r}_{\mathrm{y}} 0,579$ dengan nilai $\mathrm{n}=117$. Nilai $\mathrm{dk}=\mathrm{n}-2=117-2 \mathrm{dk}=115$

Berdasarkan hasil analisis dengan menggunakan rumus koefisien korelasi product moment yang didapat yaitu 0.579 bandingkan dengan nilai r-tabel pada taraf signifikan 0.05 dengan $\mathrm{dk}=\mathrm{N}-2=117-2=33$ adalah 0,176 . $\mathrm{r}_{\text {hitung }}(0,579)>\mathrm{r}_{\text {tabel }}(0,176)$ yang berarti ada hubungan yang sedang antara Persepsi Siswa Tentang Layanan Perpustakaan Sekolah Terhadap Motivasi Membaca siswa.

Setelah mengukur hubungan antara dua variabel tersebut dengan menggunakan koefisien korelasi product moment, maka langkah selanjutnya akan mencari koefisien 
determinasi $(\mathrm{Kd})$ untuk mengukur seberapa besar kontribusi variabel $\mathrm{X}$ terhadap variabel $\mathrm{Y}$ yaitu : $K d=r^{2} \times 100 \% K d=0,579^{2} \times 100 \%$. $K d=33,519 \%$.

Berdasarkan hasil penghitungan koefisien determinasi adalah 0,579, maka hubungan Persepsi Siswa Tentang Layanan Perpustakaan Sekolah terhadap Motivasi Membaca yaitu $33,519 \%$ dan sisanya sebesar $66,48 \%$ oleh faktor-faktor lain. Selanjutnya untuk mengetahui apakah Persepsi Siswa Tentang Layanan Perpustakaan Sekolah mempunyai hubungan yang signifikan terhadap Motivasi Membaca maka perlu dilakukan uji signifikasi korelasi dengan menggunakan uji-t. Dari uji t didapat nilain t adalah 7.615.

Berdasarkan hasil hipotesis yang didapat yaitu $t_{\text {hitung }}=7,615$ dan bandingkan dengan nilai t-tabel pada taraf signifikan 0.05 dengan $\mathrm{dk}=\mathrm{N}-2=117-2=115$ adalah 2,000. Dengan demikian kriteria penguji yang dapat diterima ialah $\mathrm{t}_{\text {hitung }}(7,615)>\mathrm{t}_{\text {tabel }}(2,000)$, maka $H_{O}$ ditolak dan $H_{a}$ diterima sehingga hipotesis yang diterima ialah "adanya hubungan yang signifikan antara Persepsi Siswa Tentang Layanan Perpustakaan Sekolah terhadap Motivasi Membaca di MAN 2 Bogor .

Interpretasi data yang disajikan berikut ini mengacu pada permasalahan yang telah dirumuskan pada Bab I. Masalah tersebut mempertanyakan apakah terdapat hubungan Persepsi Siswa Tentang Layanan Perpustakaan Sekolah Terhadap Motivasi membaca siswa di MAN 2 Bogor.

Berdasarkan hasil penelitian menunjukkan bahwa Motivasi Membaca berkriteria sangat rendah sebesar $2,56 \%$, berkriteria sedang sebesar $30,77 \%$, berkriteria tinggi sebesar $55,56 \%$ dan yang berkriteria Sangat tinggi sebesar $11,11 \%$. Dengan demikian dapat disimpulkan bahwa Motivasi Membaca di MAN 2 Bogor tergolong dalam kriteria tinggi.

Berdasarkan hasil penelitian menunjukkan bahwa Persepsi Siswa Tentang Layanan Perpustakaan Sekolah berkriteria rendah sebesar 7,69\%, berkriteria sedang sebesar 50.43\%, dan yang berkriteria 38,46\% tinggi dan berkriteria Sangat Tinggi sebesar 2,41. Dengan demikian dapat disimpulkan bahwa Persepsi Siswa Tentang Layanan Perpustakaan Sekolah di MAN 2 Bogor tergolong dalam kriteria sedang.

Berdasarkan hasil analisis dengan menggunakan rumus koefisien korelasi product moment yang didapat yaitu 0.579 bandingkan dengan nilai r-tabel pada taraf signifikan 0.05 dengan $\mathrm{dk}=\mathrm{N}-2=117-2=115$ adalah 0,176 . $\mathrm{r}_{\text {hitung }}(0.579)>\mathrm{r}_{\text {tabel }}(0,176)$ yang berarti ada hubungan yang sangat kuat antara Persepsi Siswa Tentang Layanan Perpustakaan Sekolah Terhadap Motivasi siswa.

Selanjutnya berdasarkan hasil hipotesis yang didapat yaitu $t_{\text {hitung }}=7,615$ dan bandingkan dengan nilai t-tabel pada taraf signifikan 0.05 dengan $\mathrm{dk}=\mathrm{N}-2=117-2=115$ adalah 2,000. Dengan dimikian kriteria penguji yang dapat diterima ialah $t_{\text {hitung }}>t_{\text {tabel, }}$, maka $H_{o}$ ditolak dan $H_{a}$ diterima sehingga hipotesis yang diterima ialah "adanya hubungan yang signifikan antara Persepsi Siswa Tentang Layanan Perpustakaan Sekolah terhadap Motivasi Membaca di MAN 2 Bogor .

Pembuktian Hipotesis. Berdasarkan hasil analisis dengan menggunakan rumus koefisien korelasi product moment yang didapat yaitu 0.579 bandingkan dengan nilai r-tabel pada taraf signifikan 0.05 dengan $\mathrm{dk}=\mathrm{N}-2=117-2=155$ adalah 0,176 . $\mathrm{r}_{\text {hitung }}(0.579)>\mathrm{r}_{\text {tabel }}$ $(0,176)$ yang berarti ada hubungan antara Persepsi Siswa Tentang Layanan Perpustakaan Sekolah Terhadap Motivasi Membaca Siswa, dengan demikian $\mathrm{H}_{0}$ ditolak dan $\mathrm{H}_{\mathrm{a}}$ diterima. Sebagai pedoman untuk memberikan interpretasi koefisien korelasinya maka penulis menggunakan pedoman Sugiyono (2015:257) 


\section{KESIMPULAN DAN SARAN}

\section{A. Kesimpulan}

Berdasarkan hasil pengujian hipotesis penelitian, maka dapat ditarik kesimpulan sebagai hasil penelitian ini. adapun yang penulis dapat simpulkan dari hasil penelitian ini adalah sebagai berikut :

1. Hasil penelitian ini membuktikan bahwa Persepsi Siswa Tentang Layanan Perpustakaan Sekolah di MAN 2 Bogor, setelah dilakukan perhitungan diperoleh skor terendah 37 dengan skor tertinggi 79, range skor sebesar 42, Banyak kelas sebanyak 8 , kelas interval sebanya 6 , modus sebesar 56,79, median sebesar 56,96 dan mean sebesar 56,83. Dalam persentasi rendah sebesar $7,69 \%$, berkriteria sedang sebesar $50.43 \%$, dan yang berkriteria $38,46 \%$ tinggi dan berkriteria Sangat Tinggi sebesar 2,41\%.

2. Selain itu penelitian ini membuktikan bahwa Motivasi Membaca di MAN 2 Bogor diperoleh skor terendah 28 dengan skor tertinggi 79, range skor sebesar 51, Banyak kelas sebanyak 8, Interval kelas sebesar 7, modus sebesar 55,40 median sebesar 55,83 dan mean sebesar 56, dalam persentasi sangat rendah sebesar 2,56\%, berkriteria sedang sebesar $30,77 \%$, berkriteria tinggi sebesar $55,56 \%$ dan yang berkriteria Sangat tinggi sebesar $11,11 \%$.

3. Hasil pengujian terhadap koefisien yang diperoleh dari hasil perhitungan bahwa $r_{x y} 0,579$ signifikan, sehingga terdapat hubungan antara Persepsi Siswa Tentang Layanan Perpustakaan Sekolah dengan Motivasi Membaca di MAN 2 Bogor. Hal ini dibuktikan berdasarkan hasil perhitungan $t_{\text {hitung }}$ sebesar 7,615 dan $t_{\text {tabel }}$ dengan derajat kebebasan $(\mathrm{dk})=\mathrm{N}-2$ dan $\alpha=0,05$ sebesar 2,000. Hal ini berarti $t_{\text {hitung }}>$ dari $t_{\text {tabel }}$ yakni 7,615 $>2,000$.

B. Saran

Dengan kerendahan hati penulis mengajukan beberapa saran. Ada pun saran yang dimaksud adalah sebagai berikut :

1. Untuk MAN 2 Bogor berdasarkan kepada kesimpulan dari hasil penelitian ini yang menunjukkan bahwa ada hubungan antara Persepsi Siswa Tentang Layanan Perpustakaan Sekolah dengan Motivasi Membaca Siswa di MAN 2 Bogor, sehingga diharapkan. Meningkatkan layanan perpustakaan, Menambah koleksi buku dan fasilitas perpustakaan, dan Menjadikan perpustakaan lebih menyenangkan.

2. Penulis menyadari banyaknya kekurangan karena penelitian ini masih jauh dari sempurna karena "Tak ada Gading Yang Tak Retak", oleh sebab itu diharapkan untuk kedepannya ada penelitian selain yang berhubungan dengan aktivitas guru, karena ruang lingkup dari program studi Administrasi Pendidikan tidak hanya meneliti aktivitas seorang guru dalam kegiatan belajar mengajar tetapi ada hal yang lain misalnya tentang pelayanan pendidikan.

\section{DAFTAR PUSTAKA}

Arikunto, Suharsimi. (2002). Metodologi Penelitian. Jakarta: PT. Rineka Cipta.

Arikunto, Suharsini. (2010). Prosedur Penelitian Suatu Pendekatan Praktik. Yogyakarta: Rineka CIpta.

Arsyad, dan Sulfemi, Wahyu Bagja. (2014). Minat Siswa Tentang Keadministrasian dengan Hasil Belajar Administrasi Perkantoran. Edutecno. 9 (2), 40-50.

Arsyad dan Sulfemi, Wahyu Bagja. (2018) Metode Role Playing Berbantu Media Audio Visual Pendidikan dalam Meningkatkan Belajar IPS. Jurnal Pendidikan Ilmu Pengetahuan Sosial Indonesia. 3 (2). 41 - 46. 
Bafadal, Ibrohim. (2008). Manajemen Perlengkapan Sekolah Teori dan Aplikasinya. Jakarta: Bumi Aksara.

Badar, Dadan Samsul dan Sulfemi, Wahyu Bagja. (2014). Pengaruh Rasa Percaya Diri dan Motivasi Berprestasi Terhadap Kinerja di Kecamatan Ciampea Kabupaten Bogor. Edutecno. 10 (1), 1-10

Darmono. (2007). Perpustakaan Sekolah Pendekatan Aspek Manajemen dan Tata Kelola. Grasindo

Djamarah, Syaiful Bahri. (2008), Psikologi Belajar. Jakarta: PT Rineka Cipta.

Fajartriani, Tia dan Sulfemi, Wahyu Bagja. (2014).Pengaruh Motivasi Kerja Guru dan Iklim Organisasi Terhadap Kinerja Guru SMA Negeri di Kecamatan Cigudeg. Edutecno. $8(1), 17-26$

Irwantoro Nur, (2016_, Kompetensi Pedagogik, Cet I, Surabaya : Genta Group Production. Mushaf Jejen, 2001, Peningkatan Kompetensi Guru Melalui Pelatihan dan Sumber BelajarTeori dan Praktik, Jakarta: Kharisma Putra Kencana.

Hasibuan, Malayu S.P. (2006). Manajemen Dasar, Pengertian dan Masalah. Jakarta: Bumi Aksara.

Hidayat. (2013). Manajemen Pendejatan Substansi dan implementasi dalam Praktek Pendidikan di Indonesia. Tanggerang: Pustaka Mandiri.

Karsiwan, Wawan dan Sulfemi, Wahyu Bagja. (2016). Hubungan Penerimaan Diri Dengan Kinerja Guru SD Di Kecamatan Pamijahan Kabupaten Bogor Edutecno. 15. (1). 110.

Moenir. (2014). Manajemen Pelayanan Umum di Indonesia. Jakarta: Bumi Aksara.

Mulyasa, E. (2002). Manajemen Berbasis Sekolah. Bandung: PT. Remaja Rosdakarya.

Purwanto, Ngalim. (2014). Psikologi Pendidikan. Bandung: Remaja Rosdakarya

Sinambela, Lijan Poltak. dkk. (2011). Reformasi Pelayanan Publik Teori Kebijakan dan Implementasi. Jakarta: Bumi Aksara.

Sudarsana,Undang dan Bastiano. (2014). Pembinaan Minat Baca. Tanggerang Selatan: Universitas Terbuka

Sugiyono. (2015). Metode Penelitian Kuantitatif Kualitatif dan R\&D. Bandung: Alfabeta.

Sulfemi, Wahyu Bagja. (2015). Pengaruh Metode Pembelajaran Kontekstual dan Penggunaan Media Video Pendidikan Terhadap Hasil Belajar IPS. Edutecno. 13 (2), 1-10.

Sulfemi, Wahyu Bagja. (2015). Challenges Of Indonesian Teacher Competence in dealing with Asean Economic Cummunity (AEC). Engglis Forum. 1 (1), 69-79

Sulfemi, Wahyu Bagja. (2016). Hubungan Persepsi Peserta Didik Tentang Kompetensi Guru Mata Pelajaran Sejarah dengan Hasil Belajar Mata Pelajaran Sejarah di Kelas X SMA Negeri 1 Pamijahan Kabupaten Bogor. Fascho, 5 (2), 52-70.

Sulfemi, Wahyu Bagja. (2016). Hubungan antara Persepsi Guru pada Kepemimpian Kepala Sekolah dan Motivasi Guru dengan Kinerja guru dalam Proses Pembelajaran di SMA Negeri 1 Ciomas. Fascho : Kajian Pendidikan dan Sosial Kemasyarakatan, 5 (1), 36-55. 
Sulfemi, Wahyu Bagja. (2016). Kompetensi Profesionalisme Guru Indonesia dalam Menghadapi MEA. Prosiding Seminar Nasional STKIP Muhammadiyah Bogor. 1 (1), 62-77.

Sulfemi, Wahyu Bagja. (2017). Analisis Pengaruh Motivasi dan Disiplin Terhadap Kinerja Guru (Studi Kasus di SMA Negeri 1 Pamijahan Kabupaten Kabupaten Bogor). Prosiding Seminar Nasonal STKIP Muhammadiyah Bogor. 1 (1), 342-357.

Sulfemi, Wahyu Bagja, dan Nurhasanah. (2018). Penggunaan Metode Demontrasi dan Media Audio Visual Dalam Meningkatkan Hasil Belajar Peserta Didik Mata Pelajaran IPS. Jurnal Pendas Mahakam. 3 (2). 151-158.

Sulfemi, Wahyu Bagja dan Setianingsih. (2018). Penggunaan Tames Games Tournament (TGT) Dengan Media Kartu Dalam Meningkatkan Hasil Belajar. Journal of Komodo Science Education (JKSE). 1 (1), 1-14..

Sulfemi, Wahyu Bagja, dan Zulaicha Desmiati (2018) Model Pembelajaran Missouri Mathematics Project Berbantu Media Relief Experience dalam Meningkatkan Hasil Belajar Siswa. Vol 3 (3). 232-245.

Sulfemi, Wahyu Bagja dan Hilga Minati. 2018. Meningkatkan Hasil Belajar Peserta Didik Kelas 3 SD Menggunakan Model Picture And Picture dan Media Gambar Seri. JPSD. 4 (2), 228- 242.

Sulfemi, Wahyu Bagja. (2018). Pengaruh Kemampuan Pedagogik Guru dengan Hasil Belajar IPS. Edutecno 17 (1), 1-10

Sulfemi, Wahyu Bagja. (2018). Hubungan Motivasi Belajar dengan Hasil Belajar IPS dI SMP Kabupaten Bogor. Edutecno 18 (1), 1-12

Widaryanto dan Sulfemi, Wahyu Bagja (2016). Korelasi Penguasaan TIK Guru dengan Kemampuan TIK Peserta Didik. Edutecno. 14 (1), 1-10.

Tarigan, Henry Guntur. (2008). Membaca. Bandung : Angkasa 